\title{
Factors Affecting Quality of Health Service and Patient Satisfaction in Community Health Centers in North Lampung, Sumatera
}

\author{
Mulia Yuli Widayati'), Didik Tamtomo'), Rita Benya Adriani²) \\ 1)Masters Program in Public Health, Universitas Sebelas Maret \\ 2)School of Health Polytechnics, Surakarta
}

\begin{abstract}
Background: Quality of health service and patient satisfaction are an important element in providing a health service. Assessing and evaluating a health service based on user perceptions are important for continuous improvement of health services. This study aimed to examine the factors affecting quality of health service and patient satisfaction in community health centers in North Lampung, Sumatera, Indonesia.

Subjetcs and Method: This was an analytic observational study with a cross-sectional design. This study was conducted in 25 community health centers in North Lampung, Sumatera, in January 2017. A total sample of 200 out-patients was selected for this study by simple random sampling, and stratified random sampling for community health center. The dependent variables were quality of service and patient satisfaction. The independent variables were education, income, frequency of visit, and accreditation status of community health center. Contextual effect was measured by accreditation status of community health center. The data were collected by questionnaire and analyzed by linear regression multilevel model.

Results: Factors affecting quality of health service were income $(b=-1.09,95 \% \mathrm{CI}=-5.71$ to $3.52, \mathrm{p}$ $=0.641)$, education $(\mathrm{b}=-11.48,95 \% \mathrm{CI}=-16.07$ to $-6.88, \mathrm{p}<0.001)$, and frequency of visits $(\mathrm{b}=6.88,95 \% \mathrm{CI}=2.53$ to $11.23, \mathrm{p}=0.002)$. Intraclass correlation $=6 \%$. Factors affecting patient satisfaction were income $(b=-1.07,95 \% \mathrm{CI}=-1.58$ to $-0.56, \mathrm{p}<0.001)$, education $(\mathrm{b}=-0.77,95 \% \mathrm{CI}=$ -1.31 to $-0.23, \mathrm{p}=0.005)$, frequency of visits $(\mathrm{b}=0.88,95 \% \mathrm{CI}=0.39$ to $1.38, \mathrm{p}<0.001)$, and quality of service $(b=0.04,95 \% \mathrm{CI}=0.02$ to $0.06, \mathrm{p}<0.001)$. Intraclass corelation $=13.79 \%$ indicating considerable contextual effect of accreditation status of community health center.

Conclusion: Quality of service is affected by income, education, and frequency of visits in community health center. Patient satisfaction is affected by income, education, frequency of visits, and quality of service. Accreditation status of community health center has a considerable contextual effect on patient satisfaction.
\end{abstract}

Keywords: quality of service, patient satisfaction, accreditation status, community health center, multilevel analysis

\section{Correspondence:}

Mulia Yuli Widayati. Masters Program in Public Health, Universitas Sebelas Maret, Jl. Ir. Sutami 36 A Surakarta. Email: muliayuli@yahoo.co.id

\section{BACKGROUND}

Sustainable Development Goals (SDGs) are a set of objectives, targets, and indicators of sustainable development that are universal. One of the goals of SDGs is the goal in the field of health, which the third purpose mentioned to ensure a healthy life and welfare for everyone. Indonesia also has several targeted indicators such as access to quality and affordable health services (UNDP, 2015).

The policy also has a strategic plan of Ministry of Health RI 2015-2019 that every person is entitled to receive safe, quality and affordable health services (Indonesian Health Ministry, 2016b).

The public health center is a health service facility that organizes public health 
efforts and individual health efforts of the first level, with more emphasis on promotive and preventive efforts, to achieve the highest level of public health in the working area (Indonesian Health Ministry, 2014).

Bitton et al., (2017) stated that quality of public health center service was afected by system, input, output, and outcome. Peprah and Atarah (2014) stated that quality of health service can be measured by patient satisfaction.

This is considered an integral concept for the provision of health services if they want better quality. Thus, to achieve this it is necessary to provide information on the quality of care based on the patient's experience on accepted health care then this will help health professionals identify necessary service improvements.

Quality of health services has an influence on patient satisfaction. This is in accordance with the opinion expressed by Batbaatar et al. (2016) that the indicator of the quality of health services has a strong and positive influence on patient satisfaction. The same opinion is expressed by Lankarani et al. (2016) which states that patient satisfaction is an indicator of service quality and efficiency of health services.

Patient satisfaction will lead to patient confidence in a health service and will have an effect on positive patient behavior such as unwilling to switch to other health care facilities and will recommend to others (Naidu, 2009; Kalaja, et al., 2016).

Lampung Province in 2015, including the top 10 provinces that have low growth rates of public health centers, although the ratio has not fully described the actual condition of public access to health services it can be one of the factors affecting the quality of health services (Ministry of Health RI, 2016a).
Nevertheless, the Lampung Provincial Government continues to make efforts to improve the quality of health services by accrediting public health centers and targeting until 2019 all public health centers can be accredited.

Based on the data from Lampung district health office in 2016, there are 67 community health centers from 290 community health centers have been accredited and spread all districts. Accreditation is divided into four graduation levels: 12 public accredited basic health centers, 38 middle-aged public health centers, 16 major public health centers and one accredited plenary public health center (Lampung Provincial Health Office 2015).

Efforts to improve the quality of community health center services is certainly related to the role of district government. North Lampung district health office continues to improve the quality service of community health center and patient satisfaction. However, the percentage of community health center utilization for the last 3 years has not been increased yet. The percentage of visits to community health center in North Lampung based on population as much as $52 \%$ in 2014 and 2015. The percentage of visits increased to $54 \%$ in 2016. That is, only half of the population utilizes public health services.

Based on the results of preliminary study, in October of 2017, showed that some patients who come to accredited community health centers still have complaints against community health services, such as different service procedures, health personnel were less friendly, the waiting room was less comfortable, and long process for registration and drug taking process.

This study aimed to analyze factors affecting to quality of health service and 
patient satisfaction in community health centers in North Lampung, Sumatera.

\begin{tabular}{l}
\hline \multicolumn{1}{c}{ SUBJECTS AND METHOD } \\
\hline 1. Study design \\
This was an analytic observational study \\
with cross sectional design. The study was \\
conducted in 25 community health centers, \\
North Lampung, Sumatera, in January \\
2017.
\end{tabular}

\section{Population and sample}

The target population was all patients visiting the public health center. While the source population is all patients who visit the public health center in North Lampung regency to get the service of public health center consisting of 27 public health centers.

A total sample of 200 study subjects was collected by Jumlah sampel yang dipilih sebanyak 200 by simple random sampling. As many as 25 community health center were selected by stratified random sampling. This technique was chosen because the researcher divided the population in strata according to certain characteristics ie accreditation status of community health center such as not accredited, accredited basic, middle and main.

\section{Study variable}

The dependent variables were quality of service and patient satisfaction. The independent variables were education, income, frequency of visit, and accreditation status of community health center.

\section{Operational definition of variable} Educational level was defined as the level of formal education that has been taken by the respondent.

Income was defined as as monthly income calculated from the average amount of income received by the family, whether fixed or not fixed every month, expressed in rupiah.
The frequency of visits was defined as the frequency of patients coming to health services during the past year.

Accreditation status of community health center was defined as the acknowledgment of the external section (in this case the Accreditation Commission and/ or Ministry of Health representatives) to the Public Health Center regarding the system of service delivery and quality management of the community health center in accordance with the established standards.

Health service was defined as patient's perception of a health service based on patient experience. Patient satisfaction is the result of the assessment given by the patient to the satisfaction of the generally accepted health services.

\section{Study instrument}

The data were collected by questionnaire. The validity test in this study was conducted on 30 patients who visited the community health center in North Lampung District. Content validity by removing question items that have a total itemcorrelation coefficient $<0.20$. The reliability test was measured by Cronbach alpha.

\section{Data analysis}

Characteristics of the study subjects were indicated by frequency and percentage. Bivariate analysis using Pearson correlation test. The relationship of variables studied was analyzed by multilevel analysis model. Variables at level one that directly affect the individual include income, education, the frequency of visits, quality of service while the variable located at level two that is the status of accreditation of public health center. The magnitude of influence on level one is indicated by the regression coefficient (b). While the magnitude of influence on level two is shown by the Intra Class Correlation (ICC) parameter. 
Journal of Health Policy and Management (2017), 2(2): 165-175

https://doi.org/10.26911/thejhpm.2017.02.02.08

\section{Research ethics}

The research ethics clearance was obtained from the Research Committe at Dr. Moewardi Hospital. Research ethics included informed consent, anonimity, and confidentiality.

\begin{tabular}{|c|c|c|}
\hline \multicolumn{3}{|c|}{ RESULTS } \\
\hline \multicolumn{3}{|c|}{$\begin{array}{l}\text { 1. Characteristic of the study subjects } \\
\text { Table 1. Characteristic of the study } \\
\text { subject }\end{array}$} \\
\hline $\begin{array}{l}\text { Characteristic of the } \\
\text { study subject }\end{array}$ & $\mathbf{n}$ & $\%$ \\
\hline \multicolumn{3}{|l|}{ Age } \\
\hline$<45$ years & 138 & 69 \\
\hline$\geq 45$ years & 62 & 31 \\
\hline \multicolumn{3}{|l|}{ Sex } \\
\hline Male & 65 & 33 \\
\hline Female & 135 & 67 \\
\hline \multicolumn{3}{|l|}{ Education level } \\
\hline $\begin{array}{l}\text { Not completed in primary } \\
\text { school }\end{array}$ & 17 & 8 \\
\hline Elementary school & 49 & 25 \\
\hline Junior high school & 42 & 21 \\
\hline Senior high school & 77 & 39 \\
\hline College & 15 & 7 \\
\hline \multicolumn{3}{|l|}{ Income } \\
\hline$<\operatorname{Rp} 1,367,250$ & 120 & 60 \\
\hline$\geq \operatorname{Rp} 1,367,250$ & 80 & 40 \\
\hline \multicolumn{3}{|l|}{ Type of visit } \\
\hline New visit & 43 & 22 \\
\hline Old visit & 157 & 78 \\
\hline \multicolumn{3}{|l|}{ Frequency of visit } \\
\hline$<4$ times & 106 & 53 \\
\hline$\geq 4$ times & 94 & 47 \\
\hline
\end{tabular}

Table 1 showed that mostly the study subject was aged $\leq 45$ years $(69 \%)$, female
(67\%). Table 1 showed that the study subjects were aged $\leq 45$ years (69\%), female (67\%). Based on Table 1 the age of respondents most aged $\leq 45$ years is $69 \%$ and most respondents are women that are $67 \%$. The level of education of respondents varies, most respondents are graduated from high school is $39 \%$ and at least Higher Education is $7 \%$. Revenue of respondents has the most opinion below the average of Rp1.367.250 is $60 \%$.

Respondents who were the subject of the study were the mostly long-term type of patients, which was $78 \%$ but in the past year, most had a $<4$ times visit frequency of $53 \%$.

\section{Bivariate Analysis}

Table 2 expained factors affecting to quality of servive. Income $(\mathrm{r}=-0.15 ; \mathrm{p}=0.031)$ and education $(r=-0.38 ; \mathrm{p}<0.001)$ decreased quality of service. Frequanecy of visit $(r=$ $0.26 ; \mathrm{p}<0.001)$ and accreditation status $(\mathrm{r}=$ $0.18 ; \mathrm{p}=0.009$ ) increased quality of service.

Table 3 showed factors affecting to patient satisfaction. Income $(\mathrm{r}=-0.34$; $\mathrm{p}<0.001)$ and education $(\mathrm{r}=-0.41$; $\mathrm{p}<0.001)$ decreased patient satisfaction. Frequency of visit $(\mathrm{r}=0.35 ; \mathrm{p}<0.001)$, accreditation status of community health center $(\mathrm{r}=0.36 ; \mathrm{p}<0.001)$, and quality of service $(0.49 ; \mathrm{p}<0.001)$ increased patient satisfaction.

Table 3. The results of factors affecting to quality of service by Pearson corelation

\begin{tabular}{lcc}
\hline & Variable & \multicolumn{2}{c}{ Quality of service } \\
\cline { 2 - 3 } & $\mathbf{r}$ & $\mathbf{p}$ \\
\hline Income & -0.15 & 0.031 \\
Education & -0.38 & $<0.001$ \\
Frequency of visit & 0.26 & $<0.001$ \\
Accreditation status & 0.18 & 0.009 \\
\hline
\end{tabular}


Table 3. The results of factors affecting to patient satisfaction by Pearson corelation

\begin{tabular}{lcc}
\hline \multicolumn{1}{c}{ Variable } & \multicolumn{2}{c}{ Patient satisfaction } \\
\cline { 2 - 3 } & $\mathbf{r}$ & $\mathbf{p}$ \\
\hline Income & -0.34 & $<0.001$ \\
Education & -0.41 & $<0.001$ \\
Frequency of visit & 0.35 & $<0.001$ \\
Accreditation status of community & 0.36 & $<0.001$ \\
health center & & \\
Quality of service & 0.49 & $<0.001$ \\
\hline
\end{tabular}

3. The results of multilevel analysis on factors affecting quality of service Table4. Factors affecting quality of service using multilevel model

\begin{tabular}{|c|c|c|c|c|}
\hline \multirow[b]{2}{*}{ Quality of service } & \multirow[b]{2}{*}{ b } & \multicolumn{2}{|c|}{ 95\% CI } & \multirow[b]{2}{*}{$\mathbf{p}$} \\
\hline & & $\begin{array}{c}\text { Lower } \\
\text { limit }\end{array}$ & $\begin{array}{c}\text { Upper } \\
\text { limit }\end{array}$ & \\
\hline Fixed Effect & & & & \\
\hline Income & -1.09 & -5.71 & $3 \cdot 52$ & 0.641 \\
\hline Education & -11.48 & -16.07 & -6.88 & $<0.001$ \\
\hline Frequency visit & 6.88 & 2.53 & 11.23 & $<0.001$ \\
\hline Random Effect & & & & \\
\hline $\begin{array}{l}\text { Accreditation status of community health center } \\
\mathrm{n} \text { observasi }=200 \\
\text { ICC }=0.6 \% \\
\text { Likelihood Ratio Test } \mathrm{p}=0.351\end{array}$ & 1.56 & $<0.01$ & 1153.06 & 0.002 \\
\hline
\end{tabular}

Based on the results of multilevel analysis, the variables in the fix effects group in the form of income factors play a negative role in the value of service quality and close to significant $(b=-1.09,95 \% \mathrm{CI}=-5.71$ to 3.52 , $\mathrm{p}=0.641$ ) means, the higher the patient's income then the lower in delivering value to the quality of service. Educational factors play a negative role on the quality of service $(b=-11.48,95 \% \mathrm{CI}=-16.07$ to -6.88 , $\mathrm{p}<0.001)$ means the higher the patient's education the lower in assessing the quality of service. Frequency factors play a positive role in service quality $(b=6.88,95 \% \mathrm{CI}=$ 2.53 to $11.23, \mathrm{p}=0.002$ ) that the more frequent visits to the public health center will be higher in assessing the quality of care. The value of Intra Class Correlation (ICC) $0.6 \%$ and Likelihood Ratio Test $\mathrm{p}=$ 0.351 indicates that the accreditation status of higher public health center as a random effect shows no strong effect on service quality of public health center but individual factor has more influence in assessing service quality.

\section{The results of multilevel analysis on factors affecting patient satis- faction}

Based on the results of multilevel analysis, the variables in the fixed effect group that play a role in increasing and decreasing the patient satisfaction value significantly are income $(b=-1.07$, CI $95 \%=-1.58$ to -0.56 , $\mathrm{p}=0.000)$, education $(\mathrm{b}=-0.77,95 \% \mathrm{CI}=$ 0.39 to $1.38, \mathrm{p}<0.001$ ) and service quality $(\mathrm{b}=0.04,95 \% \mathrm{CI}=0.02$ to $0.06, \mathrm{p}<0.001)$.

The result of ICC factor that influence patient satisfaction is $13.79 \%$. It shows that the accreditation status of community health center has a contextual influence on patient satisfaction variation $13.79 \%$. This figure is bigger than the standard of role of thumb size $8-10 \%$ hence the contextual influence of public health center shown 
from multilevel analysis is very important to note. In the table also indicated likelihood ratio $=0.002$. This means that there are differences and statistically significant between models regardless of contextual influences and models that take account of contextual influences. Public health centers with major accreditation status increase the likelihood of providing higher patient satisfaction than posyandu with middle and basic levels even with unaccredited ones.

Tabel 5. Multilevel analysis on the factors affecting to patient satisfaction

\begin{tabular}{|c|c|c|c|c|}
\hline \multirow{2}{*}{ Patient satisfaction } & \multirow{2}{*}{ b } & \multicolumn{2}{|c|}{$95 \% \mathrm{CI}$} & \multirow[b]{2}{*}{$\mathbf{p}$} \\
\hline & & Lower limit & Upper limit & \\
\hline \multicolumn{5}{|l|}{ Fixed Effect } \\
\hline Income & -1.07 & -1.58 & -0.56 & $<0.001$ \\
\hline Education & -0.77 & -1.31 & -0.23 & 0.005 \\
\hline Frequency of visit & 0.88 & 0.39 & 1.38 & $<0.001$ \\
\hline Quality of service & 0.04 & 0.02 & 0.06 & $<0.001$ \\
\hline \multicolumn{5}{|l|}{ Random Effect } \\
\hline $\begin{array}{l}\text { Accreditation status of community } \\
\text { health center }\end{array}$ & 0.46 & 0.08 & 2.72 & $<0.001$ \\
\hline \multicolumn{5}{|l|}{$\mathrm{N}$ observation $=200$} \\
\hline
\end{tabular}

\section{DISCUSSION
1. Factors affecting to quality of services by multilevel analysis \\ Intraclass corelation $=6 \%$ indicating consi- derable contextual effect of accreditation status of community health center.}

\section{a. The effect of income on quality of service}

Family income negatively affected to quality health service. The higher patient income, the greater patient expectation to providing quality health service from health personnel.

This finding is consistent with Mapatano et al., (2017) that the perception of quality health service depends on the patient's socioeconomic. Findik et al., (2010) stated that the successful of treatment was related to socioeconomic status. Patients with low incomes tend to provide a higher quality assessment of the health service.

\section{b. The effect of education to quality of service}

Education affected to perception on health service quality in community health service. The higher patient education, the lower the assessment of quality health service in community health service.

This finding is consistent with Péfoyo and Wodchis (2013) that patients with higher education have higher expectations of quality health service. So the patient wants a better service delivery. Larson et al., (2014) also stated that patients who higher education or exposed to more media will provide an assessment of lower quality health service.

\section{c. The effect of frequency visit to quality service}

Frequency of visit was positively associated with quality health service. The more frequent the patients visit community health center, the higher the value of quality health service. It can be assumed that patients who have recurred within the past year to the same health care facility to obtain health services mean that patients tend to be more satisfied with the quality of health services previously provided. In addition, with repeated visits made by patients within a year, causing awareness of the relationship between the officer and the 
patient, even the patient is able to be recognized by the officer.

This finding is consistent with Birhanu et al. (2010) that the frequency of visits has a relation to the perceptions of service quality given by the officers because the average visiting patient will provide a higher assessment of the quality of service. Rockers et al. (2011) also stated that the patient experience during the visit may affect the rating ratings on the perceptions of service quality provided by the officers, in addition to information on the perceived quality of services provided by these patients can be used to improve the quality of care.

\section{d. The effect of accreditation status of community health center to quality of service}

Based on the results of multilevel analysis that the value of $\mathrm{ICC}=0.6 \%$. It means the contextual accreditation status of community health centers that patients provide an assessment of the quality of service does not have a different effect.

This has enabled the process of providing services since it was established as an accredited public health center of 7 new community health centers \pm 3 months, so improvements are still being applied to provide quality services, since the main purpose of accreditation of Public Health Centers is to improve quality, performance through continuous improvement of the management system, the quality management system and the service delivery system and programs, as well as the implementation of risk management, and not only the assessment to obtain the accreditation certificate (Indonesian Health Ministry, 2015).

In addition, there is no alternative to compare the standard of service quality given that in the area only close to one public health center. So the quality value given is almost homogeneous between accredited basic, middle, and primary accredited public health centers. This is in line with Turkson's (2009) opinion that the perception of service quality can be influenced by limited knowledge of how quality service standards and alternative health care alternatives compare to quality standards. The client measures the quality of service depending on the quality of interpersonal and not only medical technical indicators. It may be ignored by healthcare providers.

According to Alhassan et al., (2015) it is important to recognize interpersonal and quality technical qualities in accordance with medical standards in the provision of health services, the balance will be felt by patients so that patients will prove the benefits and feel the existing health system even though in general accreditation program will be able to increase service processes and improving the quality of health services (Alkhenizan and Shaw, 2011; Flodgren et al., 2011).

This finding is inconsistent with Greenfield and Braithwaite (2008), that perceptions of service quality increased with primary health care accreditation. Accreditation status improves the community health center reputation and raises awareness of staff, thereby increasing patient perceptions of service quality.

\section{Factors affecting to patient satis- faction}

This study showed that the accreditation status of community health center has a contextual influence on the variation of patient satisfaction with $\mathrm{ICC}=13.79 \%$. It means that the contextual influence of accreditated community health centers is important to note in addition to the individual factors. 
Journal of Health Policy and Management (2017), 2(2): 165-175

https://doi.org/10.26911/thejhpm.2017.02.02.08

\section{a. The effect of of income on patient satisfaction}

Income was negatively affected with patients satisfaction. The higher income, the lower patient satisfaction. Patients with higher incomes will expect a more satisfactory health service. Patients will pay for satisfactory healthcare.

This finding is consistent with Lankarani et al. (2016) that a person with a higher socioeconomic status would be more dissatisfied with health services, because patients tend to be more able to express dissatisfaction with a health service compared with patients with low socioeconomic status. But, this finding is inconsistent with Mohamed et al. (2015) that income has no effect on the level of satisfaction afforded by community health center.

\section{b. The effect of education on patient satisfaction}

This study showed that patient satisfaction was negatively affected by education. It can be assumed that people with education are increasingly able to provide an objective assessment of health service satisfaction.

Lankarani et al., (2016) and Alnemer (2015) stated that lower patient's education tent to satisfaction than higher patient's education level. Rahmqvist and Bara (2010), Mohamed and Azizan (2015) also stated that education level negatively affects patient satisfaction. Although this finding is inconsistent with Babatunde et al., (2013) which stated that the higher the education of the patient the higher the level of satisfaction with the given service.

\section{c. The effect of frequency of visit on patient satisfaction}

Frequency visit was positively associated with patient satisfaction. Patients who are more frequent to the community health center are considered more satisfied with the health services. Frequent visits will lead to closeness between health personnel and patients, so that patients are more comfortable checking their health at community health center.

The more frequent the frequency of patients visiting a community health center the higher the level of satisfaction (Batbaatar et al., 2016). While Birhanu et al., (2010) stated that patients who frequently visit community health centers will have good relations with officials. Patients who knew the officer well had a higher level of satisfaction compared with those who did not know the health personnel.

Good relationship between health personnel and patient can be shown by the existence of good communication pattern between health personnel and patient. If the communication run well will be able to increase patient satisfaction so that patient intend to return to service (Larson et al., 2017).

\section{d. The effect of quality health service to patients satisfaction}

Quality of health service was positively affected with patient satisfaction. It assumed that if the patient has a high perception of the quality health service they will more satisfied with the services provided.

This finding was consistent with AlDamen, (2017) and Zamil et al., (2012), which stated that quality of health service affected by patient satisfaction. Patient satisfaction is assumed that the values in certain services provided by the officer are attached to the patient's memory and will differ in each individual so this will increase the patient's willingness to recommend, increase trust, loyalty and reduce the number of complaints, therefore quality of service often considered a preliminary to patient satisfaction (Shan et al., 2016)

Fenny et al., (2014) stated that quality of health service factors are important for the realization of patient satisfaction 
although different people may judge the same services differently because they are influenced by the expectations and characteristics of each individual.

\section{e. The effect of accreditation status to patient satisfaction}

This study showed that accreditation status of community health center has a contextual influence on the variation of patient satisfaction in general with $\mathrm{ICC}=$ 13.79\%. It means that contextual influence of public health centers with accreditation status is very important to note.

Accreditation community health centers by the standards Ministry of Health regulations No. 46 the year 2015 physically indeed provide patient comfort when visiting the community health center. Parking lot, waiting room, inspection room, clean room more comfortable at an accredited community health center.

This finding was consistent with $\mathrm{Al}$ Tehewy et al., (2009) and Ajarmah et al., (2015), which stated that the accreditation system on primary health care can affect patient satisfaction. A comprehensive accreditation system run by community health service is able to provide higher patient satisfaction compared to nonaccredited community health service.

El-Jardali et al., (2014) stated that accreditation can improve patient satisfaction with health services, decreasing patient complaints on health care, and increasing number of patient visits.

\section{REFERENCE}

$\overline{\text { Ajarmah BS, Hashem TN, Jordan A (2015). }}$ Patient satisfaction evaluation on hospitals: comparison study between accredited and non accredited hospitals in Jordan, European Scientific Journal, 11(32): 298-314.

Al-Damen R (2017). Health care service quality and its impact on patient satisfaction. Case of Al-Bashir Hospital, International Journal of Business and Management, 12(9): 136.

Alhassan RK, et al. (2015). Comparison of perceived and technical healthcare quality in primary health facilities: Implications for a sustainable National Health Insurance Scheme in Ghana', PLoS ONE, 10(10): 1-19.

Alkhenizan A, Shaw C (2011). Impact of accreditation on the quality of healthcare services: A systematic review of the literature, Annals of Saudi Medicine, 31(4): 407-416.

Alnemer KA (2015). A Multicenter study of factors affecting patient's satisfaction visiting primary health care clinics in Riyadh, Saudi Arabia, Family Medicine and Medical Science Research, 4(2): $2-5$.

Babatunde AO. et al. (2013). Primary Health Care Consumers' Perception of Quality of Care and Its Determinants in North-Central Nigeria, Journal of Asian Scientific Research, 3(7): 775785 .

Batbaatar E, et al. (2016). Determinants of patient satisfaction: a systematic review, Perspectives in public health, $\mathrm{XX}(\mathrm{X})$, pp. 1-13.

Birhanu, Z. et al. (2010) 'Determinants of satisfaction with health care provider interactions at health centres in central Ethiopia: a cross sectional study', BMC Health Services Research, 10(1): 78 .

Bitton A (2017). Primary health care as a foundation for strengthening health systems in Low and Middle-Income Countries', Journal of General Internal Medicine. Journal of General Internal Medicine, 32(5): 566-571.

Dinas Kesehatan Provinsi Lampung (2015). Profil Kesehatan Provinsi Lampung Tahun 2015', (44). 
El-Jardali F, et al. (2014). The impact of accreditation of primary healthcare centers: Successes, challenges and policy implications as perceived the impact of accreditation of primary healthcare centers: successes, challenges and policy implications as perceived by healthcare, BMC Health Services Research, 14(1): 1-10.

Fenny AP, et al. (2014). Patient Satisfaction with Primary Health Care - A Comparison between the Insured and Non-Insured under the National Health Insurance Policy in Ghana, Global Journal of Health Science, 6(4): 9-21.

Findik UY, Unsar S, Sut N (2010). Patient satisfaction with nursing care and its relationship with patient characteristics, Nursing \& Health Sciences, 12(2): 162-169.

Flodgren G. et al. (2011). Effectiveness of external inspection of compliance with standards in improving healthcare organisation behaviour, healthcare professional behaviour or patient outcomes', Cochrane Database of Systematic Reviews, (11).

Greenfield D, Braithwaite J (2008). Health sector accreditation research: a systematic review, 20(3): 172-183.

Kalaja R, Myshketa R, Scalera F (2016). Service Quality Assessment in Health Care Sector: The Case of Durres Public Hospital', Procedia- Social and Behavioral Sciences. The Author(s): 557-565.

Kemenkes RI (2014). Peraturan Menteri Kesehatan Republik Indonesia Nomor 75 Tahun 2014 tentang Pusat Kesehatan Masyarakat, 1-24. (2015). Peraturan Menteri Kesehatan Republik Indonesia Nomor 46 Tahun 2015 Tentang Akreditasi Puskesmas, Klinik Pratama, Tempat
Praktik Mandiri Dokter, dan Prakter Mandiri Dokter Gigi, Kemenkes, 33: 3-8.

(2016a). Profil Kesehatan Indonesia Tahun 2015.

(2016b). Rencana Strategis Kementrian Kesehatan Tahun 2015-2019.

Lankarani KB, et al. (2016). Satisfaction Rate Regarding Health-care Services and Its Determinant Factors in SouthWest of Iran: A Population-based Study. International journal of preventive medicine, 7: 122.

Larson E. et al. (2014). Determinants of perceived quality of obstetric care in rural Tanzania: a cross-sectional study, BMC Health Services Research, 14(1): 483.

Larson E, Leslie HH, Kruk ME (2017). The determinants and outcomes of good provider communication: a crosssectional study in seven African countries, BMJ Open, 7(6): e014888.

Mapatano J. et al. (2017) 'Measuring Patients' Perception on the Quality of Care in the Democratic Republic of Congo Using a Modified, Service Quality Scale (SERVQUAL)', 1(2), pp. 1-6. Mohamed B, Azizan NA (2015). Perceived service quality's effect on patient satisfaction and behavioural compliance, International Journal of Health Care Quality Assurance, 28(3): 300314.

Mohamed EY (2015). Patients' Satisfaction with Primary Health Care Centers' Services, Majmaah, Kingdom of Saudi of Saudi Arabia. International journal of health sciences, 9(2): 163-70.

Naidu A (2009). Factors affecting patient satisfaction and healthcare quality, International Journal of Health Care Quality Assurance, 22(4): 366-381.

Péfoyo KAJ, Wodchis WP (2013). Organizational performance impacting 
patient satisfaction in Ontario hospitals: A multilevel analysis, BMC Research Notes, 6(1).

Peprah AA, and Atarah BA (2014). Assessing Patient's Satisfaction using SERVQUAL Model: A Case of Sunyani Regional Hospital, Ghana, International Journal of Business and Social Research, 4(2): 133-143.

Rahmqvist M, Bara AC (2010). Patient characteristics and quality dimensions related to patient satisfaction, International Journal for Quality in Health Care, 22(2): 86-92.

Rockers PC, Miriam MEK, Laugesen MJ (2011). Perceptions of the Health System and Public Trust in Government in Low- and Middle- Income Countries: Evidence from the World Health Surveys, Journal of health politics, 36(6): 945-960.

Shan L. et al. (2016). Patient satisfaction with hospital inpatient care: Effects of trust, medical insurance and per- ceived quality of care', PLoS ONE, 11(10): 1-18.

$\mathrm{Al}$ Tehewy M, et al. (2009). Evaluation of accreditation program in non-governmental organizations' health units in Egypt: Short-term outcomes, International Journal for Quality in Health Care, 21(3): 183-189.

Turkson PK (2009). Perceived quality of healthcare delivery in a rural district of ghana. Ghana medical journal, 43(2): 65-70.

UNDP U (2015). Indicators and data mapping to measure sustainable development goals (SDGs) targets': 1-127.

Zamil AM, Areiqat AM, Tailakh W (2012) 'The Impact of Health Service Quality on Patients' Satisfaction over Private and Public Hospitals in Jordan: A Comparative Study. International Journal of Marketing Studies, 4(1): 123-137. 